\title{
Biodiversity and the Power of Metaphor in Environmental Discourse
}

\author{
Esa Väliverronen
}

Metaphors are an integral part of our thinking and the process of communicating our ideas to others. This holds true for scientific thinking and writing as well as for interaction between scientific and other discourses (e.g. Black, 1962; Hesse, 1970; Brown, 1986). It is sometimes argued that metaphors are virtually the only way to understand abstract issues (Lakoff \& Johnson, 1980). Particularly, studies in cognitive psychology have highlighted this role of metaphors as tools of information-processing. Indeed, it is hard to imagine how abstract scientific theories and concepts could be 'popularised' or successfully 'translated' into semi-professional or lay discourses without metaphors.

It is particularly through metaphors that science becomes a part of political struggles, administrative discourses and everyday conversation. Environmental issues are a good example. This has partly to do with the fact that many environmental problems, most prominently the latest 'big issues' such as acid rain, ozone depletion or climate change are mainly abstract, theoretical constructions that are only observable with highly advanced technical apparatuses, models and theories. We can neither see nor feel them but need metaphors like the 'ozone hole' and the 'greenhouse effect' to make these issues more concrete.

There is a vast body of literature defining what a metaphor is and how it should be studied, how metaphors and their uses should be classified, etc. I will not go into that discussion here. Instead I refer only to a broad definition of metaphor and concentrate on the various uses and functions of metaphors in environmental discourse.

Kenneth Burke defines metaphor in terms of perspective: "Metaphor is a device for seeing something in terms of something else. It brings out the thisness of that, or the thatness of this" (Burke, 1989: 247). Thus, metaphor allows us to see something in a new light. Perspective has a dual character: it may reveal something new, but also hide something 
else. (However, see Burke, 1984; 1989: 247-251 on the differences between metaphor and perspective.)

Some recent accounts of the role of metaphors in social and cultural studies of science have described metaphors as 'media of exchange' (Bono, 1990) and 'messengers of meaning' (Maasen, 1995; Maasen \& Weingart, 1995) between different disciplines, discourses and other social contexts. Metaphors have an important role to play in the communication between different disciplines and in the interaction between science and society at large. This approach differs from a more linguistic notion of metaphor in the sense that it aims to analyse metaphor within a broader context, i.e. that of a discourse.

Discourse is nowadays a very widely used term, referring variously to everyday talk or conversation as well as to more 'scientific' uses as a particular area of language use and knowledge production, so that it can mean almost anything. Foucault (1972: 49) defines discourses as "practices that systematically form the objects they speak". This lends discourse a constitutive role, not only in purposes for which language is used, but also in our 'making of the world'. Thus discourse is not just a group of words or statements, but has a constitutive role in the sense that it produces something more than that. Discourses have effects, often conceptualised as power. Foucault connected discourses and the power of discourses to institutions such as science or different scientific disciplines and disciplinary-based practices. Yet, differences emerge between the early 'archaeologist' and the later 'genealogist' Foucault. In his later works Foucault (e.g. 1981) began to think of discourses as being more cross-disciplinary and heterogeneous, and not solely based on certain institutions and disciplinary practices.

\section{The Functions of Metaphors}

It may be tempting to see the role of metaphors in environmental discourse and politics only in terms of popularisation in the sense of oversimplifying scientific knowledge or in terms of political persuasion, by playing on people's emotions. The use of simple catchwords that condense complex processes and that appeal to our common experience is of course a part of environmental discourse and political rhetoric in general. However, I think that metaphors perform other functions as well. In order to study these different uses and consequences of metaphors, I have made a distinction between the communicative function and the connective function of metaphors. This distinction is made for heuristic purposes only, to highlight different aspects of the process of metaphorisation.

By the communicative function, I refer to the role of metaphor as a 'medium of exchange' or a 'messenger of meaning'. Metaphors make communication and interaction possible by providing a 'common ground' for making sense of communicated concepts and ideas. In the interaction between scientific and non-scientific discourses, this can also be defined as popularisation, but of course this definition comprises only part of the process of bringing science to everyday life (Väliverronen, 1993). The connective function of metaphors refers to the role of metaphors in connecting different disciplines, levels of argumen- 
tation, discourses and practices.

It may sound trivial to point to the communicative function of metaphors. However, metaphors are not like any other words or figures of speech that are able to transmit information or meanings trough interpretation. Instead, they perform a special role in communication between different discourses, disciplines or institutions. Communication is not only about transporting or transmitting something - sound, images, information, ideas, etc. - but also making something common and shared, as Raymond Williams (1988: 72) has pointed out. Particularly in this latter sense, metaphors are important devices of communication. By their familiarity, or at least their ability to evoke commonly shared meanings and feelings, they function as a 'common ground' for interdiscursive change and communication. (On the role of metaphors as common grounds in the media discourse, see, e.g. Hellsten 1997.) This makes metaphors not 'just' figures of speech but constitutive elements of rhetoric and argumentation.

For Burke (1989: 179-188) the use of metaphors as well as other tropes is based on identification. This concept, being a key term in his analysis of rhetoric (Gusfield 1989), points to the relation between the speaker and his/her audience. It means not only identifying things having certain properties and belonging to a larger whole but also identifying common interests and feelings proposed by the speaker.

As communicative devices, metaphors may turn out to be useful tools in opening scientific and other specialist fields to public discourse and deliberation. They help to provide a common language and more equal opportunities for participation. In solving such complex scientific, technical and social problems as those involving the threats to the environment, this may be indispensable. But, this virtue may of course turn into a vice. Metaphors can also be used as means of reinforcing scientific and professional authority or ways of promoting certain political, economic or other interests. When science-based metaphors are successfully introduced into lay discourses, they may produce not only a better understanding of science, but also reinforce the role of science as a social institution and a mode of knowledge production in society and culture.

In order to be effective, metaphors must resonate in multiple contexts and at multiple levels of discourse. This also means that metaphors may have many and sometimes contradictory meanings. Everyone who uses a metaphor does necessarily use it in the same way or agree with the normative connotations implied. Perhaps we can only say that successful metaphors establish a 'common ground' for those different interpretations and feelings, forming a basis on what to agree or disagree. As well as being 'common grounds' metaphors can also turn out to be 'uncommon grounds' or 'battlegrounds': we may be using the same words but have different meanings for them. I will return to this question later in discussing biodiversity as a 'boundary object'.

The meanings and functions performed by metaphors, vary considerably between different contexts. One example is the use of health and illness as metaphors in environmental discourse. In the study of the acid rain and forest 
decline debate in Finland between 1980 and 1995 (Väliverronen, 1996) I found that these metaphors were commonly used in order to describe the state of forest and trees. The concept of forest health was introduced to public discourse through scientific surveys which indicated a decline in the health of the forests in many parts of Finland in the late 1980s. The concept of forest health, which is itself an ambiguous concept in forest research (Innes 1993) was further modified by the media discourse. This was manifested in the slogan 'the forest is sick' that became symptomatic for the state of the environment in general. The forests in Lapland were supposed to die because of massive air pollution from the Russian Kola Peninsula.

The general idea of disease in forests was later conveyed in the metaphor of the 'cancer forest', which symbolised the serious effects of air pollution. One source of this redefinition was again scientific discourse, a particular disease affecting the health of the trees, gremmeniella canker, which was called in Finnish versosyöpä (something that could be translated as 'sprout cancer'). However, in the public debate, this particular disease gained a much broader meaning by evoking the frightening connotations of cancer. The extension of the metaphor became a powerful means of connecting human health with the health of nature. This connection has not been very evident in the case of acid rain and forest decline. This is because the forests most effected by the acid rain in the late 1970s and early 1980s in Europe, lied usually far from urban areas, and because the direct effects on human health were not supposed to be very strong. So it has been typical to talk about the acid rain problem in dramatic and sometimes apocalyptic terms (Hannigan, 1995: 132).

As connective devices metaphors are used to mobilise thinking and action in certain directions by evoking feelings and establishing links with already existing norms. In the theories of metaphor, this function has been ascribed to 'generative metaphors' (Schön, 1993), which act as perspectives or frames that serve to shape thinking and behaviour. Schön uses the term of 'normative leap' to describe the role of the metaphor in bridging the gap between scientific thinking and political action.

For example, the metaphor of the 'greenhouse effect' is effective in making abstract theories more concrete. It also evokes feelings, for example, of nice tropical places where plants grow well. On this basis it has also been criticised by one meteorologist who said that the metaphor should be abandoned because it cannot motivate action. He suggested that it should be placed with a term like the "global heat trap" (Schneider, 1989: 59; Litfin, 1994: 39).

It should also be stressed that the functions of a metaphor can be only analysed in a broader discursive context, not just by pondering the possible meanings of certain terms. The functions of acid rain, ozone hole or greenhouse effect as metaphors depend largely on how they are interpreted as symbols of the 'environmental crisis' or particular ways of dealing with it. This kind of metaphorisation refers to the 'topicality' (Myerson \& Rydin, 1996) or the 'emblematic' (Hajer 1995) nature of environmental discourse. Environmental discourse proceeds mainly through certain major topics or emblems which 
function as metaphors or more precisely as metonyms for the general global threat to the environment. New topics introduce new ways to speak and argue, i.e. new discourses, but there is also obvious continuity between different topics, and this continuity manifests itself in metaphors.

This means that in order to understand the functions of metaphors between scientific and political domains, we need to look at their place in culture and society at large. One interesting example is the study of Chungling Kwa (1987) on the rise of ecosystems-ecology and the International Biological Programme (IBP) 1968-74. Kwa argues that the metaphor of the cybernetic machine "fulfilled an intermediary role between ecologists and politicians during this important stage of development of American ecology" (Kwa, 1987: 414). Ecology, which had institutionally a rather weak status compared to other natural sciences, became part of 'Big Science'. This change was part of larger changes in scientific thinking, i.e. the rise of cybernetic thinking, which reached from various disciplines and fields of research to political arenas and lay discourse. The main point that Kwa makes in relation to the functions of metaphors is, that "this change cannot be understood as the mere product of negotiating and lobbying" (Kwa, 1987: 434). Hajer (1995) in his study on the politics of acid rain, makes a similar point arguing that environmental politics cannot be understood solely on the basis of the competition between interest groups and advocacy coalitions, but that discursive elements, such as metaphors and story-lines may have a constitutive role in politics.
However, the role of metaphors as connective devices does not necessarily require a common understanding of the basic assumptions of certain theories or shared interests and values invested in particular political metaphors. The building of actor-networks composed of scientists, engineers, policy-makers, interest groups, journalists, etc. for certain scientific and political projects, is sometimes based on rather loose and temporary connections or common interests. In this case metaphors function as 'boundary objects' which "maximize both the autonomy and communication" between different social worlds (Star \& Griesemer, 1989: 404). According to Star and Griesemer, boundary objects are "objects which are both plastic enough to adapt local needs and the constraints of the several parties employing them, yet robust enough to maintain a common identity across sites" (Star \& Griesemer, 1989: 393). Although Star and Griesemer apply the concept of boundary object to objects like museums, diagrams, maps or formulas, it could also be used to describe the role of biodiversity in science and environmental discourse.

\section{The Proliferation of Biodiversity Discourses: Science, Politics, and the Media}

Biodiversity has made a transformation from a scientific concept into a political slogan within the space of just over a decade. During the 1990s it has become the latest "big" environmental issue, comparable to acid rain, ozone depletion and climate change. Biodiversity, sometimes described as "the richness and variety of life on Earth" or "the story 
of life on Earth" (Jeffries, 1997: 3) has given a new perspective to a number of environmental issues such as the conservation of wilderness areas like tropical rain forests, the mass extinction of species, the preservation of genetic resources for agriculture or sometimes to the possibility of a global environmental catastrophe in general.

In linguistic terms, biodiversity is not an obvious metaphor; it does not give a more concrete shape to abstract ideas by connecting the familiar and unfamiliar. It is hardly a new root metaphor in biology or ecology, because diversity has long roots in biological thinking and it is difficult to trace its 'source domain'. However, if we apply the qualifier metaphor "to any term whose diffusion into ever-new contexts we wish to study" (Weingart \& Maasen, 1997: 477), we may say that biodiversity is a new metaphor in scientific, administrative and media discourses.

As a scientific concept, biodiversity brings together three different levels: genetic, species and ecosystem diversity. Variety and heterogeneity are essential aspects of the dynamics of life at all these levels. This conceptual invention, depicted in terms of biotic diversity or biological diversity, is usually traced to the late 1970s and early 1980s and to the birth of a new discipline, i.e. conservation biology. The idea of biodiversity also has its roots in ecology, evolutionary biology, genetics and environmental ethics (Haila \& Kouki, 1994; Potthast 1996).

The strong connection to a new discipline, conservation biology, makes biodiversity somewhat different from previous big environmental issues. It has been argued, that "the location of biological diversity at the centre of the dis- cipline of conservation biology means that, unlike acid rain, global warming and other more cross-disciplinary scientific problems, it has been buffered against the 'issue-attention cycle'" (Hannigan, 1995: 161).

Biodiversity was acknowledged as a global environmental problem during the UN conference on environment and development in Rio de Janeiro in June 1992. Together with global warming, biodiversity was the central issue on the agenda of the meeting as well in public debates around it. The U.S. president George Bush provided good publicity for the issue by his unwillingness "to save squirrels if it costs one American job" (Jeffries, 1997: 1). The Convention on Biological Diversity was signed by 155 states during the conference and it forms a basis for monitoring and conservation programs as well as various research programs at the level of nation states.

As a new big environmental issue both globally and locally, biodiversity has also penetrated into many new disciplines and fields of research, including the social sciences. Finland is "a front runner in putting into practice the research commitments adopted from the Convention Biological Diversity" (Fibre Newsletter 1/1997: 2). The funding for the Finnish Biodiversity Research Programme 1997-2002 is estimated to be 110 million FIM (appr. 22 million USD) for six years, which is a major research investment in a small country. The programme was launched by the Academy of Finland but it is also financed by such institutions as the Technology Development Centre and Ministry of Transport and Communications as well as by other ministries and organisations. For the first three years, the programme funds 
58 research projects and almost 250 scientists studying eight subject areas: forestry and silviculture, agriculture, aquatic environments, conservation biology and systematics, microbiology and biotechnology, socio-cultural aspects of biodiversity, developing countries and environmental law.

\section{The Social Construction of Biodiversity}

The case of biodiversity provides a good opportunity to study the 'social construction' of a concept and a social problem. It first appeared as an abbreviation of biological diversity in the National Forum on BioDiversity (see Wilson 1988), organised in Washington D.C. in September 1986. The Forum was "an explicitly political event” (Takacs, 1996:37) and the shorthand, which quickly established itself without the capital D, was purposefully invented and addressed to the U.S. Congress and the general public. The Forum gained a lot of publicity in the U.S. media trough such prominent spokespersons as Paul Ehrlich and Edward O. Wilson. They and some other well-known scientists called themselves the Club of Earth and announced that "the species extinction crisis is a threat to civilisation second only to the threat of thermonuclear war". This aroused public interest also because mass extinction had become a public topic just one year before because of new asteroid theories presented to explain the fate of dinosaurs (Mazur \& Lee, 1993).

Scientists, particularly conservation biologists, played a major role in the 'construction' of the biodiversity crisis as a new environmental problem. According to Takacs, "as a result of a determined and vigorous campaign by a cadre of ecologists and biologists over the past decade, biodiversity has become a focal point for the environmental movement" (Takacs, 1996: 1).

However, this is only part of the story. And I think that Takacs partly exaggerates the role conservation biologists played in putting biodiversity on the global environmental agenda. This would not have succeeded without the growing economic importance of biotechnology. The financial value of genetic resources has been widely recognised through intellectual property rights, and new developments in biotechnology have paved the way to the use of biodiversity as a new type of natural resource (Hannigan, 1995). The interests of big multinational corporations and new trends of globalising economy had a strong impact on the U.N. biodiversity convention (Nissi, 1997). Thus, biodiversity is rapidly being commercialised.

The birth of the concept biological diversity is usually traced to the late 1970s and early 1980s and the emergence of conservation biology (e.g. Hannigan, 1995; Jeffries, 1997), although the term itself was perhaps first used in a title of a scientific paper in 1972 (Kaennel, 1998: 74). Conservation biology was formally recognised as a discipline in 1985 with the creation of the Society for Conservation Biology. Yet, it was only the coining of the neologism biodiversity in 1986, that made the concept more widely used in scientific literature (see figure 1). Nowadays these two terms are used as synonyms although biological diversity may have "a more scientific flavour" than its popular abbreviation (Kaennel, 1998: 74).

The Society for Conservation Biology 
Figure1. Biodiversity publications in the Science Citation Index 1985-1997.

Number of articles containing terms 'biodiversity' or 'biological diversity' in titles or abstracts of scientific journals. Source of data: SciSearch.

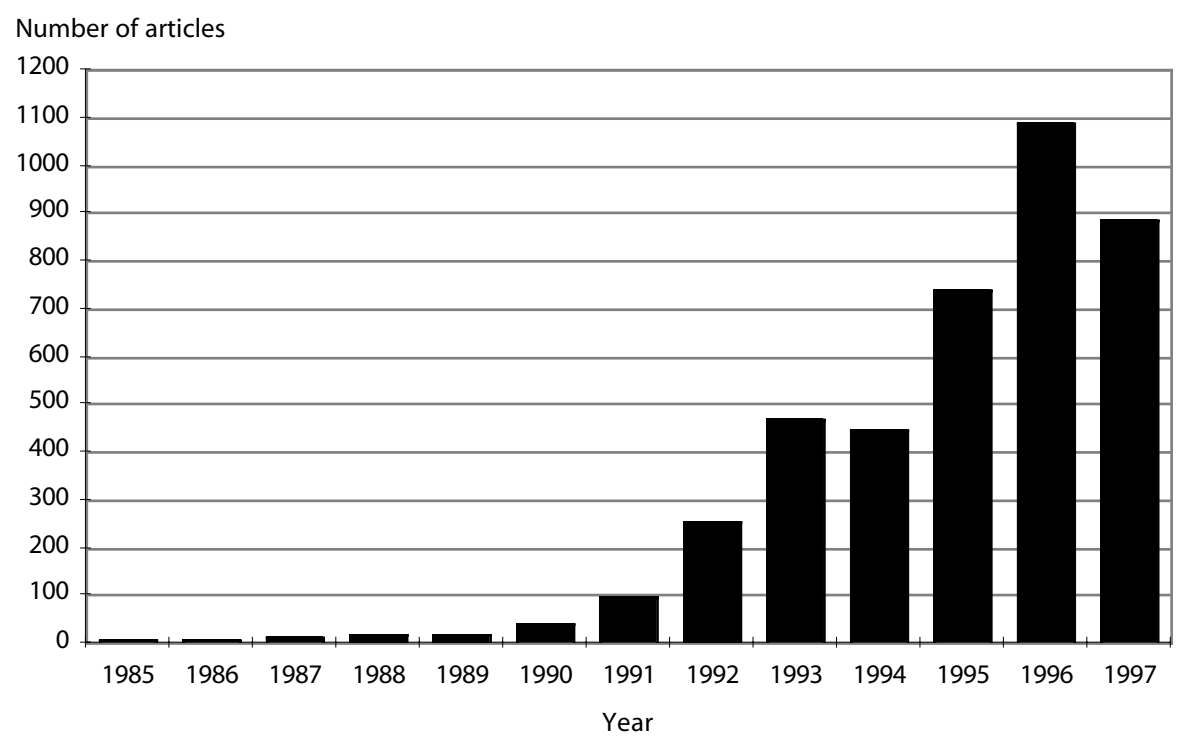

has been described as being "among the most rapidly growing professional societies in history (Noss, 1993: 215). Its journal, Conservation Biology, which first appeared in 1987 with four issues and about 100 pages per issue, has now six issues per year with about 250 pages.

\section{Semantic Diversity}

The definition of biodiversity as a scientific concept brings together three entities or levels of natural systems: genes, species and ecosystems. Genetic diversity, the range of genetic information coded in the DNA, is considered to be the basis for permitting organisms to adapt environmental change. Species diversity, referring to the variety of species found in an ecosystem, is important to the dynamics and functioning of the ecosystem. Ecosystem diversity refers to the variety of habitats in a particular region or community.

This trilogy has been presented as a standard definition in scientific papers as well as policy documents (for general reviews see, e.g. Gaston, 1996; Kaennell, 1998). However these definitions have also been criticised as ambiguous and 'descriptively complex', i.e. several criteria can be used to characterise and measure 'biodiversity', and the results do not necessarily coincide (Haila \& Kouki, 1994).

From a different perspective, biodiversity is "not an entity, a resource but a property, characteristic of nature" (Solbrig, 1994). A major feature of the biodiversity issue is that it brings forth a conceptual revolution in our understanding of living nature. Biodiversity is a characteristic of life: processes of life are based on heterogeneity and variation 
that is fundamentally stochastic in nature. This emphasis on the historical and stochastic nature of biological diversity offers an analogy to the breakthrough of 'chaos' in scientific thinking, for instance, climatology. The implications are similar, too: human possibilities to manage and control processes of nature are quite limited. This perspective on biodiversity shifts the focus from entities to processes in nature, introducing a "processual turn" for viewing biodiversity (Haila, 1998).

Some definitions of biodiversity also point to cultural diversity as part of biological diversity. Global Biodiversity Strategy (1992) by World Resources Institute, The World Conservation Union and United Nations Environment Programme uses the concept of cultural biodiversity in viewing the dependency of social and cultural systems on the ecological system. Cultural diversity is manifested by diversity in language, religious beliefs, cultivation practices, social structures, etc. (1992: 3). Yet, there may be major controversies in combining the conservation of biodiversity and the protection of cultural diversity, such as the rights and social systems of indigenous peoples (e.g. Baumann et al., 1996; Shiva, 1993).

The concept of diversity is not a new invention in biological thinking. "From Linnaeus to Darwin to the present era of cladograms and molecular evolution, a central theme of biology has always been the diversity of life." (Ehrlich \& Wilson, 1991: 758). However, Ernst Mayr in his book The Growth of Biological Thought, points to the shifts of meaning and various uses of this concept. A major shift, according to Mayr, was that from 'essentialist (typological) thinking' to 'popula- tion thinking' (Mayr, 1982: 47) in the 19th century. This innovation can be mainly attributed to Darwin and his theory of evolution and natural selection. Darwin was the first to fully understand the unique role of individuals (organisms, plants, humans, etc.) not only of types, for the dynamics of living nature. Variation in nature, which essentialist thinking had explained as error, was now seen as the real basis of natural selection.

Despite these conceptual changes, and acknowledging the semantic diversity described above, it remains an open question, how the term biodiversity is actually used in the various scientific disciplines, professional discourses of environmental policy and public debates. Some critics have already argued that previous essentialist assumptions lurk in environmental policy and management discourses (Litvin, 1997) or that the nature-culture dualism may be reinforced in the conservation discourses and practices of biodiversity (Haila, 1998).

\section{The Role of Biodiversity in Science and Environmental Discourse}

Biodiversity has multiple functions in different contexts and discourses. As a boundary object, biodiversity provides a basis for several research projects, conservation programmes and biotechnological applications. It is plastic enough to adapt local, contextual definitions but robust enough to maintain a common identity for these projects and their actor-networks. It is interesting how the discourses of biodiversity "move fairly effortlessly from conceptual definition, to information and measurement, to the consideration of global and local prac- 
tice” (Myerson \& Rydin, 1996: 77). The internal incoherencies and possible sources of controversy surrounding the definition of biodiversity have remained latent. Controversies that have been characteristic of the acid rain and climate change issues, for instance, seem to be lacking.

Firstly, as a scientific concept, biodiversity works as an umbrella term (Haila \& Kouki, 1994) combining different disciplines, perspectives and levels of biological research. This has given rise to a growing body of biodiversity research, not only in biological sciences, but also in many other fields. (On the growth of biodiversity publications in social sciences see figure 2)

The notion of biodiversity provides a research programme to survey and clas- sify all forms of life on Earth. There is a new information 'big-bang' (Myerson \& Rydin, 1996: 67) for assessing and measuring the Earth's biological diversity. Thus, biodiversity evokes the old obsession of botanists and zoologists with classification and taxonomy (Mayr, 1982) in such projects as the Global Biodiversity Assessment (Heywood \& Watson, 1995), which is considered of as a kind of new Bible of biodiversity. This is manifested in the metaphors such as the 'book of life' and 'library', which are commonly used in defining biodiversity as well as in the rhetoric of the Human Genome Mapping (Rosner \& Johnson, 1995).

Secondly, biodiversity provides a new perspective in environmental discourse. It combines and articulates in a new way

Figure 2. Biodiversity publications in the Social Science Citation Index 1985-1997. Number of articles containing terms 'biodiversity' or 'biological diversity' in titles or abstracts of scientific journals. Source of data: Social SciSearch.

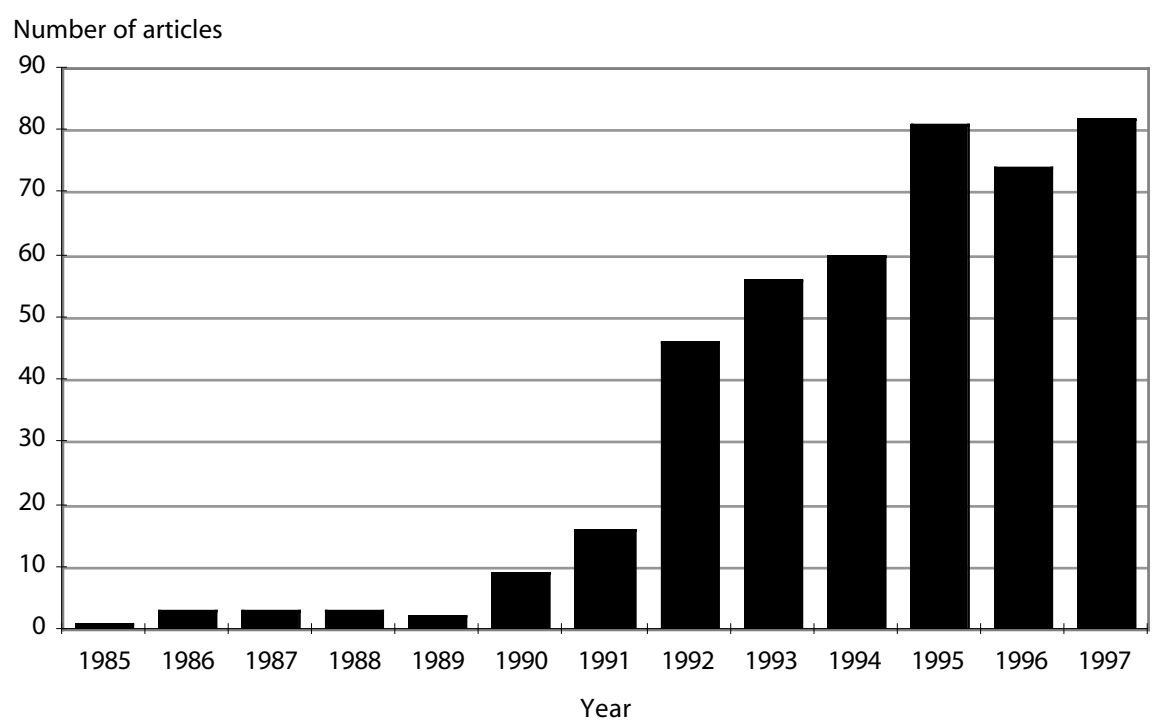


previous environmental concerns, such as the extinction of species and the protection of wilderness by giving them a scientific grounding. This means that biodiversity functions as a symbol or metonymy for the environmental concerns at large.

However, the issue of biodiversity also shows some continuities to previous environmental discourses. In public discussion and environmental politics, the idea of biodiversity is usually conceptualised either at the level of the species or of the gene. On the one hand, biodiversity has provided a basis for apocalyptic narratives of the rapid extinction of species due to human intervention. This evokes previous environmental concerns such as the 'population bomb', 'limits of growth' and 'mass extinction'. On the other hand, biodiversity has given rise to a new narrative of hope based on gene technologies: tropical rainforests are presented as a magic well for modern biotechnology and the pharmaceutical industry. Biodiversity is a new resource to be systematically monitored and prospected, providing new exotic foods and cures, even a cure for cancer.

These two narratives and perspectives are - at least to some extent - combined in the discourse of 'sustainable development'. This slogan, introduced by the Brundtland Report, Our Common Future (World Commission, 1987), also formed the basis for the convention signed in Rio. Sustainable development consists of the idea of combining economic growth and the needs of nature conservation by sustainable use and management of nature (Hajer, 1995).

Thirdly, biodiversity provides a new natural resource and raw material to be prospected, calculated and technologically modified. Thus, it can be valued as biological capital. This brings forth the idea of 'the life industry' (Baumann et al., 1996). The image of tropical rainforests as the 'magic well' of the pharmaceutical industry has also helped to translate the idea of biodiversity into the realm of popular culture in such films as Medicine Man, in which Sean Connery appears as a scientist who discovers a cure for cancer in South American rainforests.

Fourthly, biodiversity provides an object and programme for conservation and environmental management. New styles of forest management and conservation planning are being introduced. However, it remains an open question, how these new styles actually differ from traditional nature conservation. This again emphasises the context-specificity of the biodiversity discourse (Haila \& Kouki, 1994).

\section{Meanwhile in the Jungle: the Popular Image of Biodiversity in the Media}

Biodiversity did not cause very much public interest before the year 1992, despite the successful launching of the term in the U.S. media during the National Forum in 1986. However, two issues closely linked to biodiversity, namely mass extinction of species and the rapid destruction of rain forests became popular topics, at least in the U.S. media in the late 1980s (Mazur \& Lee, 1993; Collins \& Kephart, 1995). These issues became part of the agenda of global environmental problems, most notably discussed in terms of ozone depletion and global warming. Biodiversity 
Figure 3. Articles on biodiversity in the newspapers New York Times and Times/Sunday Times 1988-1997. Number of articles containing terms 'biodiversity' or 'biological diversity'.

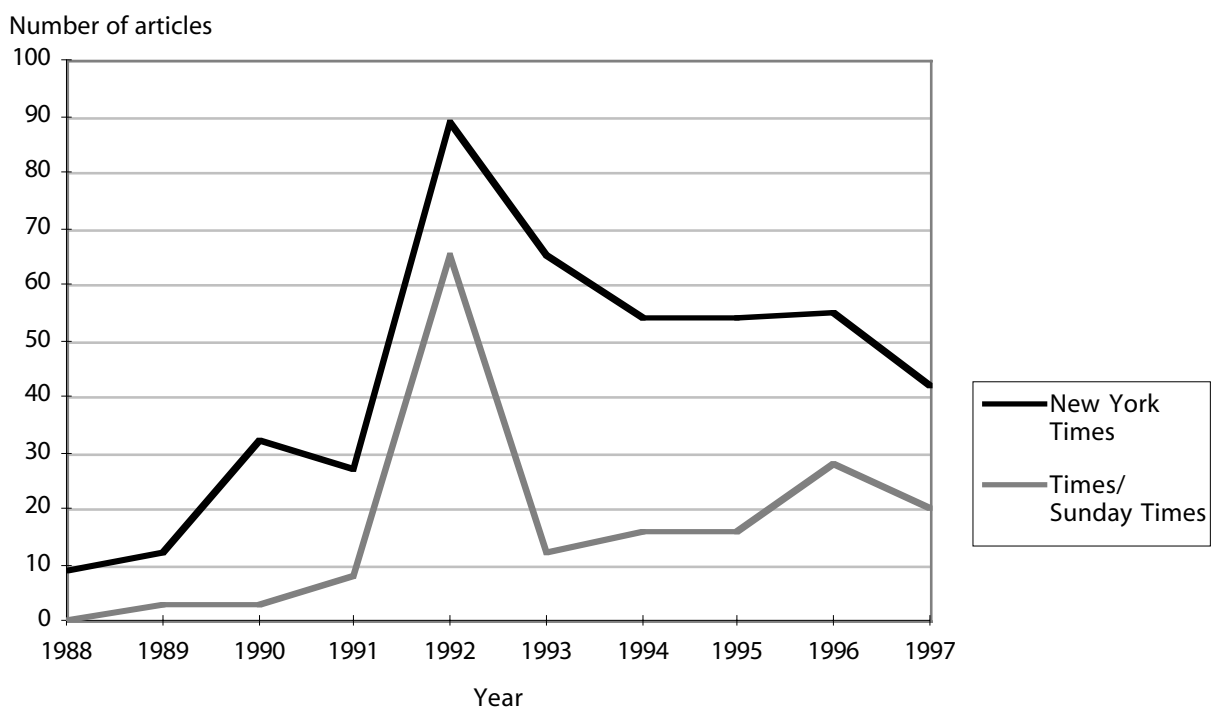

was also slowly imported to Europe, and the year of the Rio conference made a short peak in the media attention on biodiversity. After this, the media coverage has again slowly risen, but again stabilised and perhaps lost some of its popularity after 1996 (see figure 3), such as in the case of scientific publications.

Mass extinction and the destruction of rain forests have also heavily influenced the popular image of biodiversity loss in the 1990s as "these problems were energetically publicised by a network of influential biologists with foundation support and good contacts to the national news organs" (Mazur \& Lee, 1993: 708). 'Going public' has been part of the mission of conservation biologists ever since the birth the discipline (e.g. Soulé, 1986).

In the media, biodiversity is often symbolised and visualised by photographs of charismatic, 'photogenic', ani- mals used by environmental organisations in their campaigns. Further, the use of numbers has provided a powerful argument on behalf of the extinction crisis. The photographs and satellite pictures of burning rain forests became a symbol of the destruction of the world's biodiversity. The popular image of the tropical forest itself has also been transformed by the mass media "from one of dark foreboding jungle, sweltering and bug infested, to that of an emerald green paradise" (Mazur \& Lee, 1993: 711).

Biodiversity is thus a deeply symbolic issue. After the big 'pollution issues' such as acid rain, ozone depletion and climate change, it brings forth the variety and beauty of nature. This means that through the idea of biodiversity we now may see our nature differently. This positive popular image of biodiversity is reinforced by the fact that biodiversity seems to lack the controversies typical 
of other major environmental issues. This does not mean that the discussion of various aspects of biodiversity is consensual (see, e.g. Baumann et al., 1996; Myerson \& Rydin, 1996; Shiva, 1993; Weizsäcker, 1993). However, the potential sources of controversy on issues like development and democracy, NorthSouth relations, property rights, rights of indigenous peoples, ecotourism or biotechnology, have not had very much influence on the popular image of biodiversity.

Yet, there are some exceptions. For example in some African countries biodiversity may be a curse. This is because, in 1996 Professor Obel, Kenyan Chief Scientist to the President, marketed a cure for aids that was manufactured by a company called Biodiversity. This expensive new medicine, called Pearl Omega, was withdrawn from sale later in the year following international press coverage. "In the developed world biodiversity has become such a popular buzz word that articles increasingly sneer at this jargon” (Jeffries, 1997: 36).

\section{From Science to Politics: Biodiversity as a Metaphor}

In conservation biology, there is also a strong connection between science and ethics. Biodiversity is often described as a 'crisis discipline' and the professional community "is fighting a brave battle" in "the war to save tropical biodiversity" (Janzen, 1987: 95). According to Soulé (1986: 6), "in crisis disciplines in contrast to normal 'science', it is sometimes imperative to make an important tactical decision before one is confident in the sufficiency of the data". This notion of conservation biology as a 'crisis disci- pline' and 'mission-orientated' is often repeated in the editorials of Conservation Biology (e.g. Wilcox, 1987; Meffe, 1998).

There is also another project in conservation biology to extend the boundaries of science to politics. Its most prominent spokesman, Edward O. Wilson, has aimed to develop an ultimate basis for conservation ethics determined on a genetic basis. This is part of his "program of disciplinary imperialism" (Takacs, 1996: 331) manifested first in Sociobiology (1975) and developed later in Biophilia (1984). Using the concept of biophilia, Wilson argues that the love of nature is a universal adaptation of humans selected through the course of evolution.

Taking all this together, it is obvious that biodiversity is not just a normal scientific concept. It is often used as an allencompassing term, a "scientized synonym for nature” (Takacs, 1996: 107). "When reading and listening to the definitions biologists apply to biodiversity, it is hard to imagine what in nature does not fall under the rubric of the term" (Takacs, 1996: 75).

Biodiversity is about almost anything that is good and under a threat in our natural environment. The power of biodiversity as a metaphor in semiprofessional and popular discourses is also linked to its origin as a scientific concept: it "shines with the gloss of scientific respectability" (Takacs, 1996: 99). This is an important feature of metaphors in relations between scientific and lay discourses. They do not only carry meanings but also power and authority (Weingart, 1995). Metaphors are powerful means of communicating authority and credibility from one discursive 
field to another. For example numbers, statistics and graphics can function as metaphors in their supposed ability to carry the ethos of objectivity of science.

Biodiversity makes connections between many disciplines, including ecology, evolutionary biology, environmental management, environmental ethics and new technological applications, such as those developed by biotechnology. In addition, it is manifested in various forms, representing pre-Darwinian ideas for taxonomy and classification as well as 20th century theories of evolutionary biology (see, e.g. Potthast 1996). Thus, biodiversity is itself diverse, carrying multiple perspectives, arguments and associations. Perhaps it is all this that makes biodiversity such a powerful metaphor for environmental research.

It is possible to argue that the success of biodiversity in scientific and political arenas is not so much based on the status of biodiversity as a conceptual invention but as a 'buzzword' (Angermeier, 1994) or 'bandwagon' (Rodda, 1993), performing a 'fashion effect' (Kaennel, 1998) in environmental research and science policy. Along with other bio-neologisms such as biotechnology, biomedicine, bioethics, biopolitics, biosociality, bioregional, etc. it has become part of a 'biocultural' transformation in contemporary society.

\section{Acknowledgements}

Previous versions of this paper were presented at the 5th Pori workshop on environmental policy, Pori, Finland, 26-30 August 1998 and at the EASST '98 General Conference, Session Metaphors and Knowledge Dynamics, Lisbon, Portugal, 1-3 October 1998. Thanks are due to Yrjö Haila and Peter Taylor, the organisers of the Pori workshop and to Sabine Maasen and Peter Weingart, the organisers of the EASST session.

\section{References}

Angermeier, P. L.

1994 "Does biodiversity include artificial diversity?" Conservation Biology 8: 600602.

Baumann, M. et al. (eds.)

1996 The Life Industry: Biodiversity, People and Profits. London: Intermediate Black, M. Technology Publications.

1962 Models and Metaphors. Studies in language and philosophy. Ithaca and New Bono, J. York: Cornell University Press.

1990 "Science, discourse and literature: The role/rule of metaphor in science". In Peterfreund S. (ed.) Literature and science. Boston: Northeastern University Press.

Brown, R. H.

1986 "Rhetoric and the science of history". Quarterly Journal of Speech 72: 148161.

Burke, K.

1984. Permanence and Change: an Anatomy of Purpose. Berkeley: University of California Press.

1989 On Symbols and Society. Chicago and London: The University of Chicago Press.

Collins, C. and Kephart, S.

1995 "Science as news: The emergence and framing of biodiversity" Mass Communications Review 22(12): 21-41.

Ehrlich, P. \& Wilson, E.O.

1991 "Biodiversity studies: science and policy”. Science 253: 758-762.

Fibre - Newsletter: The Finnish biodiversity research programme 1/1997.

Foucault, M.

1972 The Archaeology of Knowledge. London: Tavistock Publications.

1981 The History of Sexuality. An Introduction. Harmondsworth: Penguin Books.

Gaston, K.J.

1996 "What is biodiversity?" In Gaston K.J. (ed.) Biodiversity: a biology of numbers and difference. Oxford: Blackwell. 
Global Biodiversity Strategy: Guidelines for action to save, study and use Earth's biotic wealth sustainably and equitably.

1992 World Resources Institute, The World Conservation Union, United Nations Gusfield, J.

Environment Programme.

1989 “Introduction" in Burke, K., On Symbols and Society. Chicago and London: The Haila, Y. University of Chicago Press.

1998 "Biodiversity" and the Nature - Culture Divide: Conflicting Tendencies. Manuscript. University of Tampere: Department of Regional Studies and Environmental Policy.

Haila, Y. and Kouki, J.

1994 "The phenomenon of biodiversity in conservation biology" Ann. Zool. Fennica 31: 5-18.

Hajer, M.

1995 The Politics of Environmental Discourse: Ecological Modernization and the Policy Process. Oxford: Clarendon Press.

Hannigan, J.

1995 Environmental Sociology. London: Routledge.

Hellsten, I.

1997. "The door to Europe or outpost towards Russia? - Political metaphors in Finnish EU journalism". In Koivisto, J. \& Lauk, E. (eds.) Journalism at the Crossroads. Tartu and Tampere: Tartu University Press.

Hesse, M.

1970 "The explanatory function of metaphor". In Bar-Hillel, Y. (ed.) Logic, Methodology and Philosophy of Science. Amsterdam: North-Holland Publishing Company.

Heywood, V.H. and Watson, R.T. (eds.)

1995 Global Biodiversity Assessment. Cambridge: UNEP and Cambridge UniverInnes, J.L. sity Press.

1993 "Methods to estimate forest health" Silva Fennica 27(2): 145-157.

Janzen, D.

1987 “Editorial”, Conservation Biology 1(2): 95-96.

Jeffries, M.

1997 Biodiversity and Conservation. London and New York: Routledge.

Kaennel, M.

1998 "Biodiversity: A diversity in definition" in Bachmann, P. et al. (eds.) Assessment of Biodiversity for Improved Forest Planning 71-81. European Forest Institute Proceedings no. 18.

Kwa, C.

1987 "Representation of nature mediating between ecology and science policy: The case of the International Biological Programme". Social Studies of Science 17 (1987): 413-42.

Lakoff, G. and Johnson, M.

1980 Metaphors We Live By. Chicago: Chicago University Press.

Litfin, K.

1994 Ozone Discourses. NewYork: Columbia University Press.

Litvin, D.

1997 "The discourse of diversity: from biology to management" Organization: discourse and organization 4(2): 187-209. Maasen, S.

1995 "Who is afraid of metaphors". In Maasen, S. Mendelsohn, E. and Weingart P. (eds.) Biology as Society, Society as Biology: Metaphors. Dordrecht Boston and London: Kluwer.

Maasen, S. and Weingart, P.

1995 "Metaphors - messengers of meaning". Science Communication 17 (1): 9-31.

Mayr, E.

1982 The Growth of Biological Thought: Diversity Evolution and Inheritance. Cambridge Massachusetts and London England:The Belknap Press of Harvard University Press.

Mazur, A. and Lee, J.

1993 "Sounding the global alarm: Environmental issues in the US National News" Social Studies of Science 23: 681-720.

Meffe, G.K. 1998 “Conservation biology: Into the Millennium”. Conservation Biology 12 (1): 1-3.

Myerson, G. and Rydin, Y.

1996 The Language of Environment: A New Rhetoric. London: UCL Press.

Nissi, S.

1997 The Biodiversity Regime - A Means for the Global Economy. A study on international institutionalization of a techno-economic discourse of biodi- 
versity. Unpublished Master's Thesis. University of Tampere: Department of Political Science.

Noss, R.

1993 "Whither conservation biology?" Conservation Biology 7(2): 215-217.

Potthast, T.

1996 "Inventing biodiversity: genetics, evolution, and environmental ethics". Biologisches Zentralblatt 115: 177-188.

Rodda, G.H.

1993 "How to lie with biodiversity". Conservation Biology 7: 959-960.

Rosner, M. and Johnson R.T.

1995 "Telling stories: Metaphors of the Human Genome Project". Hypatia 10 (4): 104-129.

Schneider, S.

1989 "The greenhouse effect: science and policy". Science 243: 771-781.

Schön, D.A.

1993 "Generative metaphor: A perspective on problem-setting in social policy". In Ortony A. (ed.) Metaphor and Thought. Second edition. Cambridge University Press.

Shiva, V.

1993 "The greening of the global reach" in W. Sachs (ed.) Global Ecology: A New Arena of Political Conflict. London and New Jersey: Zed Books.

Solbrig, O.T.

1994 "Biodiversity: an introduction". In Solbrig O.T. et al. (eds.) Biodiversity and Soulé, $\mathrm{M}$. Global Change. Wallingford.

1986 "Conservation biology and the 'real world”. In Soulé M. (ed.) (1986) Conservation Biology: The Science of Scarcity and Diversity. Sunderland Massachusetts: Sinauer Associates Inc.

Star, S.L. and Griesemer, J.

1989 "Institutional ecology, translations and boundary objects: amateurs and professionals in Berkeley's museum of vertebrate zoology 1907-39". Social Studies of Science 19: 387-420.

Takacs, D.

1996 The Idea of Biodiversity. Philosophies of Paradise. The Johns Hopkins University Press: Baltimore and London.
Väliverronen, E.

1993 "Science and the media: Changing relations". Science Studies 6 (2): 23-34.

1996 Ympäristöuhkan anatomia. Tiede, mediat ja metsän sairaskertomus (Anatomy of an environmental threat: science, the media and the story of forest dieback). Tampere: Vastapaino.

Weingart, $\mathrm{P}$.

1995 “'Struggle for existence': Selection and retention of a metaphor". In Maasen, S. Mendelsohn, E. and Weingart P. (eds.) Biology as Society, Society as Biology: Metaphors. Dordrecht Boston and London: Kluwer.

Weingart, P. and Maasen, S.

1997 "The order of meaning: the career of chaos as a metaphor". Configurations 5: 463-520.

Weizsäcker, C.

1993 "Competing notions of biodiversity" in W. Sachs (ed.) Global Ecology: A New Arena of Political Conflict. London and New Jersey: Zed Books.

Wilcox, B.

1987 "Editorial”, Conservation Biology 1(3): 188-189.

Williams, R.

1988 Keywords: A Vocabulary of Culture and Society. London: Fontana Press.

Wilson, E.O.

1975 Sociobiology: The New Synthesis. Cambridge Mass.: Harvard University Press.

1984 Biophilia. Cambridge Mass.: Harvard University Press.

Wilson, E.O. (ed.)

1988 Biodiversity. Washington: National Academy Press.

World Commission on Environment and

Development

1987 Our Common Future. Oxford: Oxford University Press.

Esa Väliverronen

Department of Communication

University of Helsinki

Helsinki, Finland 